\title{
THE CARE AND FEEDING OF ADULTS WITH DOUBTS ABOUT CHILDREN.
}

\author{
By Logan Clendening.
}

John Bale Sons \& Danielsson, Ltd., 83-91, Great Titchfield Street, W.1. Price 6/-.

In these days of newspaper medicine, societies and faddists, all preaching how much food we should take, the number of calories that should be consumed, the amount of exercise that should be indulged in-to say nothing of advice and fashions as regards alcohol, the bringing up of children and the like- it is perhaps refreshing to find a doctor, out of his own experience (which is obviously considerable) writing a book maintaining that the old ways were best. The author definitely declares himself to be in favour of many of the ideas of the early Victorians and brings considerable evidence, not only from his own experience, but from published writings, to show to what an absurd degree the pendulum has swung to the modern side.

Perhaps the author is most illuminating and certainly most amusing when he is discussing the iniquities of so-called birth control, and perhaps the best criterion of his criticism is the way in which he very nearly proves that such a scheme is in many cases impossible. His views on diet, on weight reducing, on alcohol and exercise appear to the reviewer to be full of common sense. The appearance of this work is timely as a corrective to many fads, fashions and theories which are so prevalent to-day-often preached without any good evidence of their virtue and, in too many cases, wilfully blind to the harm that they cause.

The book is written in a definitely racy style and in places is most amusing and possibly even a little "broad"'. Nevertheless, there is one chapter with which we thoroughly disagree, and that is the chapter on nurses. Certainly the author's comments on this branch of the profession are unjust and uncalled for, and, if his experience has been such as he hints then we cannot believe that he has met with nurses of the best type. We are sorry to say that this chapter would have been much better omitted, as it spoils a book which shows much careful thought, which is set down in readable fashion, which is entertaining, and which for the most part is full of sound common sense.

\section{MATERNAL MORTALITY AND MORBIDITY}

\author{
By Prof. J. M. Munro Kerr, M.D., F.r.F.P.S.(Glas.), F.C.o.G. \\ Messrs. E. \& S. Livingstone, Edinburgh. 25/- nett.
}

In his book, Maternal Mortality and Morbidity, Professor J. M. Munro Kerr has assembled information on the problem from all available sources. Following an Introduction, the work is divided into four parts. The first part deals with the causes, sociological factors and statistical evidence receive each a long chapter. There is also a full review of the pathology and bacteriology of puerperal sepsis. The influence of Abortion on Maternal Mortality is considered from its ethical and humanitarian aspects. The importance is demonstrated of the remote effects of Maternal Mortality and subsequent disablement. Part two, entitled Prevention, is concerned with antenatal and intranatal care, and in this respect an inspection of the limited value of ante-natal work deserves especial mention. The third part reviews the maternity services as they exist to-day. The maternity hospitals, the midwife service, and the training of the medical student in Obstetrics are analysed fully. The fourth, and last part, is the author's scheme for a National Maternity Service. This suggested service was outlined in 1931 in the Journal of the Royal Sanitary Institute and 